\title{
Skrining Fitokimia dan Aktivitas Penyembuhan Luka Bakar Ekstrak Etanolik Morinda Citrifolia L. pada Kulit Kelinci (Oryctolagus Cuniculus)
}

\section{Phytochemical Screening and Activity of Ethanolic Leaves Extract Morinda Citrifolia L. Against Healing Burn in Rabbit Skin (Oryctolagus Cuniculus)}

\author{
Margareta Retno Priamsari ${ }^{1 *)}$, Noor Auly Yuniawati² \\ marga_rhee@yahoo.co.id \\ ${ }^{1}$ Program Studi D3 Farmasi, Politeknik Katolik Mangunwijaya, Jl. Gajah Mada 91 Semarang, \\ Indonesia
}

\begin{abstract}
Abstrak
Luka bakar adalah rusaknya kesatuan atau komponen jaringan yang disebabkan oleh perubahan suhu, zat kimia, listrik, dan radiasi. Senyawa alkaloid, flavonoid, saponin, dan tanin dalam daun mengkudu (Morinda citrifolia. L) berpotensi dalam penyembuhan luka bakar. Penelitian ini bertujuan untuk mengetahui skrining fitokimia dan aktivitas ekstrak etanolik daun mengkudu terhadap penyembuhan luka bakar pada kulit kelinci.

Jenis penelitian adalah eksperimental dengan rancangan acak kelompok pola searah. Ekstrak etanolik daun mengkudu diperoleh dengan metode remaserasi menggunakan pelarut etanol $96 \%$ dan dilakukan pengujian skrining fitokimia. Pengujian luka bakar dilakukan pada 5 ekor kelinci jantan galur New Zealand. Setiap bagian kulit punggung kelinci terbagi menjadi 5 perlakuan, yaitu kontrol positif (Bioplacenton gel), kontrol negatif (vaselin flavum), dan ekstrak etanolik daun mengkudu konsentrasi $10 \%, 15 \%$, dan $20 \%$. Bagian kulit punggung diinduksi lempeng logam panas berdiameter $2 \mathrm{~cm}$ selama 10 detik hingga terjadi luka bakar derajat II dangkal. Parameter penyembuhan luka bakar meliputi pengamatan visual rata-rata fisiologis dan berkurangnya diameter luka selama 21 hari. Hasil rata-rata persentase penyembuhan luka dianalisis statistik non parametrik dengan Kruskal-Wallis, dilanjutkan Mann-Whitney dengan taraf kepercayaan 95\%.

Hasil penelitian menunjukkan bahwa ekstrak etanolik daun mengkudu mengandung senyawa alkaloid, flavonoid, saponin dan tanin serta memiliki aktivitas penyembuhan luka bakar. Adanya variasi konsentrasi ekstrak etanolik daun mengkudu 10\%;15\% dan $20 \%$ tidak berpengaruh secara signifikan terhadap penyembuhan luka bakar.
\end{abstract}

Keywords: Morinda citrifolia L; ekstrak etanolik; skrining fitokimia; Superficial second degree burns

\begin{abstract}
Burns are damage to the unit or network components caused by changes in temperature, chemicals, electricity, and radiation. Alkaloid, flavonoid, saponin, and tannin compounds in Noni leaves (Morinda citrifolia. L) have the potential to heal burns. The aim of this study was to
\end{abstract}


determine phytochemical screening and the activity of noni leaf extract to the healing of burns on rabbit skin.

This type of research is experimental with a randomized pattern design in one direction. Noni leaf ethanolic extract was obtained by remaseration method using $96 \%$ ethanol solvent and phytochemical screening tests. Tests of burns were carried out on 5 male New Zealand strain rabbits. Each part of the rabbit's back skin was divided into 5 treatments, namely positive control (Bioplacenton gel), negative control (vaselin flavum), and ethanolic extract of noni leaf concentrations of $10 \%$, $15 \%$, and $20 \%$. The skin of the back is induced by a $2 \mathrm{~cm}$ diameter hot metal plate for 10 seconds until a shallow second degree burn occurs. Burn wound healing parameters include visual observation of physiological mean and reduction in wound diameter for 21 days. The average percentage of wound healing was analyzed by non-parametric statistics with Kruskal-Wallis, followed by Mann-Whitney with a confidence level of $95 \%$.

The results showed that the ethanolic extract of noni leaves contained alkaloids, flavonoids, saponins and tannins as well as having burn healing activities. The variation in the concentration of ethanolic extract of noni leaves is $10 \% ; 15 \%$ and $20 \%$ have no significant effect on the healing of burns.

Keywords: Morinda citrifolia L; Noni leaf ethanolic extract; phytochemical screening; Healing burns

\section{Pendahuluan}

Luka adalah rusaknya kesatuan atau komponen jaringan dimana secara spesifik terdapat substansi jaringan yang rusak atau hilang (Wijaya \& Putri, 2013). Luka bakar merupakan salah satu penyebab utama trauma dan penyebab umum kecacatan atau kematian akibat kecelakaan di seluruh dunia (Ardabili dkk, 2016). Luka bakar dapat mengakibatkan kerusakan kulit yang dapat meningkatkan resiko terjadinya infeksi dan komplikasi yang memerlukan penanganan (Moenadjat, 2009). Penanganan luka bakar bertujuan untuk mencegah infeksi pada luka, memacu pembentukan jaringan kolagen, dan mengupayakan agar sisa-sisa sel epitel dapat berkembang sehingga dapat menutup permukaan luka (Syamsuhidayat \& Jong, 2004).

Daun mengkudu mengandung saponin, triterpen, tanin, alkaloid, glikosida iridoid, dan flavonoid (West dkk, 2009). Penelitian Senja dkk (2017), menunjukkan bahwa salep ekstrak etanol daun mengkudu dapat menyembuhkan luka sayat pada kelinci dengan konsentrasi $10 \%$, 15\%, dan 20\%. Berdasarkan hasil penelitian tersebut, maka pemanfaatan daun mengkudu perlu dilakukan pengembangan. Pada ekstrak etanolik daun mengkudu perlu dilakukan skrining fitokimia dan potensinya dalam menyembuhkan luka bakar pada kulit kelinci.

\section{Metode Penelitian}

\section{Tatacara Penelitian}

Daun mengkudu yang digunakan yaitu daun berwarna hijau tua pada ruas ke 4-5 dari pucuk daun. Selanjutnya disortasi dicuci, dirajang, dan dikeringkan di bawah sinar matahari dengan ditutup kain hitam. Simplisia kemudian diblender dan diayak. Serbuk simplisia kemudian dilakukan pengujian kontrol kualitas meliputi uji organoleptis, susut pengeringan, dan perhitungan rendemen.

Ekstraksi daun mengkudu dilakukan dengan metode maserasi menggunakan pelarut etanol 96\%. Serbuk simplisia sebanyak $400 \mathrm{~g}$ dimasukkan bejana maserasi dan ditambahkan $2 \mathrm{~L}$ etanol $96 \%$ selama $1 \times 24$ jam. Filtrat kemudian disaring dan ditampung. Residu diremaserasi dengan 1,5 L etanol 96\% selama 1x24 jam. Filtrat yang diperoleh dijadikan satu, kemudian diuapkan pada waterbath dengan suhu $40^{\circ}-50{ }^{\circ} \mathrm{C}$ hingga terbentuk ekstrak kental. Ekstrak kental yang diperoleh dilakukan uji kontrol kualitas ekstrak meliputi organoleptis, susut pengeringan dan rendemen. 


\section{Skrining Fitokimia Ekstrak Etanolik Daun Mengkudu}

Pembuatan larutan uji dilakukan dengan menimbang 0,2 g ekstrak dilarutkan dalam 20 $\mathrm{mL}$ air panas, aduk homogen.

a. Uji Alkaloid

Sebanyak $10 \mathrm{~mL}$ larutan uji $+5 \mathrm{~mL} \mathrm{HCl}$ $2 \mathrm{~N}$, dibagi menjadi 3 tabung reaksi. Tabung pertama sebagai blanko, tabung kedua ditambah pereaksi Dragendroff, dan tabung ketiga ditambah pereaksi Mayer. Terbentuknya endapan orange pada tabung kedua dan endapan putih hingga kekuningan pada tabung ketiga menunjukkan adanya alkaloid (Jones \& Kinghorn, 2006).

b. Uji Flavonoid

Sebanyak $2 \mathrm{~mL}$ larutan uji $+2 \mathrm{~mL}$ etanol + $0,5 \mathrm{~g}$ serbuk $\mathrm{Mg}+3$ tetes $\mathrm{HCl}_{\text {(pekat) }}$. Terbentuk larutan berwarna merah-jingga menunjukkan adanya flavonoid (Jones \& Kinghorn, 2006).

c. Uji Saponin

Sebanyak 0,1 g ekstrak $+10 \mathrm{~mL}$ air panas, dinginkan, kocok 15 menit +2 tetes $\mathrm{HCl}$ 2N. Terbentuk buih selama 10 menit menunjukkan adanya saponin (Jones dan Kinghorn, 2006).

d. Uji Tanin

Sebanyak $2 \mathrm{~mL}$ larutan uji $+1 \mathrm{~mL} \mathrm{FeCl}_{3}$ 10\%. Jika terbentuk warna biru tua, biru kehitaman atau hitam kehijauan menunjukkan adanya senyawa tanin (Jones dan Kinghorn, 2006).

Uji Bebas Etanol Dalam Ekstrak Etanolik Daun Mengkudu

Uji bebas etanol dilakukan dengan metode esterifikasi, sebanyak 0,5 gram ekstrak etanolik daun mengkudu ditambah $2 \mathrm{~mL}$ asam asetat dan $2 \mathrm{~mL}$ asam sulfat. Reaksi positif bebas etanol ditunjukkan dengan tidak terciumnya bau ester yang wangi. Jika masih tercium ester berarti masih ada etanol yang mengalami esterifikasi (Praeparandi dalam Ariando, 2013).

\section{Pembuatan Luka Bakar}

Pembuatan luka bakar dilakukan dengan mencukur bulu kelinci, selanjutnya didesinfeksi dengan etanol 70\%. Kulit kelinci dianastesi dengan Topsy cream dan dibiarkan selama 60 menit. Induksi luka bakar dilakukan dengan lempeng berdiameter $2 \mathrm{~cm}$ yang telah dipanaskan dalam air mendidih $100^{\circ} \mathrm{C}$ selama 3 menit dan ditempelkan pada kulit punggung kelinci selama 10 detik tanpa disertai dengan penekanan (Erlia dkk, 2014).

\section{Pengujian luka bakar}

Pengujian luka bakar dilakukan dengan cara mengoleskan ekstrak etanolik daun mengkudu sebagai bahan uji, Bioplacenton gel sebagai kontrol positif, dan vaselin flavum sebagai kontrol negatif. Masing-masing perlakuan dioleskan sebanyak 0,2 g. Pengolesan dilakukan setiap pagi, kemudian ditutup dengan kasa steril. Pengukuran ratarata diameter luka bakar dilakukan berdasarkan penelitian Razak \& Ervianingsih (2017), seperti pada gambar:

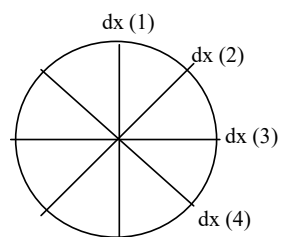

Pengukuran rata-rata diameter luka bakar diukur diameter rata-ratanya dengan rumus:

$$
\mathrm{dx}=\frac{d x(1)+d x(2)+d x(3)+d x(4)}{4}
$$

$\mathrm{dx}$ : diameter luka hari ke-x

\section{Perhitungan Persentase Penyembuhan Luka Bakar}

Perhitungan persentase penyembuhan luka bakar dilakukan setelah luka bakar terbentuk. Pengamatan dilakukan setiap pagi hari selama 21 hari dengan parameter kesembuhan yaitu berkurangnya diameter luka bakar yang ditandai dengan merapat dan menutupnya luka.

Perhitungan persentase penyembuhan luka bakar dilakukan dengan rumus:

$$
\frac{L 1-L n}{L 1} \times 100 \%
$$

Keterangan:

L1 = Luas luka bakar awal $\left(\mathrm{H}_{0}\right)$

$\mathrm{Ln}=$ Luan luka bakar hari ke-n

\section{Hasil Dan Pembahasan}

\section{Kontrol Kualitas Simplisia dan Ekstrak Etanolik Daun Mengkudu}

Hasil organoleptis simplisia daun mengkudu berbentuk serbuk, berwarna hijau tua, berbau khas. Nilai rendemen yang dihasilkan serbuk yaitu $15,90 \%$ b/b. Hasil uji susut pengeringan sebesar $8 \%$ dan telah memenuhi persyaratan Depkes RI (2000). 
Hasil uji organoleptis ekstrak etanolik daun mengkudu berbentuk kental, berwarna hijau kehitaman, berbau khas dan rasa pahit. Rendemen yang dihasilkan sebesar 22,48\% b/b. Hasil uji susut pengeringan ekstrak sebesar 6,49\% dan memenuhi persyaratan Depkes RI (2000) yaitu kurang dari $10 \%$.

\section{Skrining Fitokimia Ekstrak Etanolik Daun Mengkudu}

a. Uji senyawa alkaloid

Hasil pengujian pada ekstrak etanolik daun mengkudu positif mengandung alkaloid, ditandai dengan endapan orange pada penambahan reagen Dragendroff dan endapan putih pada penambahan reagen Mayer. Endapan yang terbentuk merupakan kompleks kalium-alkaloid (Suyatno \& Risky, 2014).

b. Uji senyawa flavonoid

Hasil pengujian pada ekstrak etanolik daun mengkudu positif mengandung flavonoid. Senyawa flavonoid tereduksi dengan penambahan magnesium dan $\mathrm{HCl}$ sehingga menghasilkan senyawa kompleks yang menimbulkan warna merah jingga (Suyatno \& Risky, 2014).

c. Uji senyawa saponin

Ekstrak etanolik daun mengkudu positif mengandung senyawa saponin. Timbulnya buih selama 10 menit menunjukkan adanya glikosida yang mempunyai kemampuan membentuk busa dalam air yang terhidrolisis menjadi glukosa dan senyawa lainnya (Nugrahani dkk, 2016).

d. Uji senyawa tanin

Hasil pengujian pada ekstrak etanolik daun mengkudu menunjukkan positif mengandung senyawa tanin. Terbentuknya warna hijau kehitaman setelah penambahan $\mathrm{FeCl}_{3}$ karena tanin membentuk senyawa kompleks dengan ion $\mathrm{Fe}^{3+}$ (Nugrahani dkk, 2016).

\section{Uji Aktivitas Penyembuhan Luka Bakar Pada Kulit Kelinci}

Uji aktivitas luka bakar dilakukan untuk mengetahui pengaruh perbedaan konsentrasi ekstrak etanolik daun mengkudu. Luka bakar pada hewan uji disebabkan karena kulit hewan uji kontak langsung dengan objek panas, menggunakan lempeng yang terbuat dari logam sebagai penghantar panas (Erlia dkk, 2014). Topsy krim sebagai zat penganestesi mengandung lidocain dan prilocaine yang bekerja dengan cara melepasan lidocain ke dalam lapisan epidermis dan dermal sehingga terjadi akumulasi lidocain disekitar target reseptor dermal pain dan di ujung-ujung saraf. Hal tersebut menimbulkan efek anestesi lokal. Luka bakar yang terbentuk adalah luka bakar derajat II dangkal dengan ciri kemerahan pada bagian kulit dan terbentuk edema (Gurnida \& Lilisari, 2011).

Pengamatan secara visual terhadap fisiologis kulit yang mengalami luka bakar dilakukan setiap 3 hari selama 21 hari.

\section{Tabel 1. Pengamatan Visual Rata-rata} Terhadap Fisiologis Luka Bakar

\begin{tabular}{|c|c|c|c|c|c|c|c|c|c|c|}
\hline \multirow{2}{*}{ Kelompok } & \multirow{2}{*}{ Keterangan } & \multicolumn{9}{|c|}{ Pengamatan Visual Rata-rata Luka Bakar Hari ke- } \\
\hline & & 0 & 1 & 3 & 6 & 9 & 12 & 15 & 18 & 21 \\
\hline \multirow{3}{*}{ Kontrol positif } & Wama & $P$ & PM & $\mathrm{CM}$ & $\mathrm{CM}$ & $\mathrm{C}$ & CT & PC & $\mathrm{PC}$ & $\mathrm{P}$ \\
\hline & Terbentukscab & - & - & $\checkmark$ & $\checkmark$ & 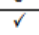 & & & & \\
\hline & Scab terlepas & - & - & - & - & - & $\sqrt{ }$ & $\checkmark$ & $\checkmark$ & $\checkmark$ \\
\hline \multirow{3}{*}{ Kontrol negatif } & Wama & $P$ & PM & $\mathrm{CM}$ & $\mathrm{C}$ & CT & CT & CT & $\mathrm{PC}$ & $\mathrm{PC}$ \\
\hline & Terbentukscab & - & - & $\checkmark$ & $\bar{v}$ & $\checkmark$ & $\checkmark$ & & & \\
\hline & Scabterlepas & - & - & - & - & - & - & $\checkmark$ & $\checkmark$ & $\checkmark$ \\
\hline \multirow{3}{*}{$\begin{array}{l}\text { Ekstrak } \\
\text { EtanolikDaun } \\
\text { Mengkudu } \\
10 \%\end{array}$} & Wama & $P$ & PM & $\mathrm{CM}$ & $\mathrm{CM}$ & $\mathrm{CM}$ & $\mathrm{C}$ & CT & PC & $\mathrm{PC}$ \\
\hline & Terbentukscab & - & - & $\checkmark$ & $\checkmark$ & $\checkmark$ & & & & \\
\hline & Scab terlepas & - & - & - & - & - & $\checkmark$ & $\checkmark$ & $\checkmark$ & $\checkmark$ \\
\hline \multirow{3}{*}{$\begin{array}{l}\text { Eksstrak } \\
\text { Etanolik Daun } \\
\text { Mengkudu } \\
15 \%\end{array}$} & Wama & $P$ & PM & $\mathrm{CM}$ & $\mathrm{CM}$ & $\mathrm{C}$ & CT & CT & $\mathrm{PC}$ & $\mathrm{PC}$ \\
\hline & Terbentukscab & - & - & $\checkmark$ & $\checkmark$ & $\checkmark$ & & & & \\
\hline & Scab terlepas & - & - & - & - & - & $\checkmark$ & $\checkmark$ & $\checkmark$ & $\checkmark$ \\
\hline \multirow{3}{*}{$\begin{array}{l}\text { Ekstrak } \\
\text { Etanolik Daun } \\
\text { Mengkudu } \\
20 \%\end{array}$} & Wama & $P$ & PM & $\mathrm{CM}$ & $\mathrm{CM}$ & $\mathrm{C}$ & CT & PC & $\mathrm{PC}$ & $\mathrm{PC}$ \\
\hline & Terbentuks $s c a b$ & - & - & $\checkmark$ & $\checkmark$ & $\checkmark$ & & & & \\
\hline & Scab terlepas & - & - & - & - & - & $\checkmark$ & $\checkmark$ & $\checkmark$ & $\checkmark$ \\
\hline
\end{tabular}

Keterangan :

$$
\begin{array}{ll}
\text { P } & =\text { Putih } \\
\text { PM } & =\text { Putih Kemerahan } \\
\text { CM } & =\text { Cokelat Kemerahan } \\
\text { C } & =\text { Cokelat } \\
\text { CT } & =\text { Cokelat Tua } \\
\text { PC } & =\text { Putih Kecokelatan } \\
(\checkmark) & =\text { Ada } \\
(-) & =\text { Tidak ada }
\end{array}
$$

Perubahan warna kemerahan pada luka menunjukkan penyembuhan luka pada fase inflamatori. Pada fase inflamatori terjadi permeabilitas membran sel sehingga terjadi peradangan, kemerahan, panas, dan nyeri (Ariando, 2013). Pada fase ini terjadi peristiwa hemostatis, dibantu oleh benang-benang fibrin sehingga sel darah merah beserta plasma akan terjaring membentuk gumpalan. Gumpalan ini akan membentuk scab (keropeng) (Sentat \& Permatasari, 2015).

Pembentukan scab menunjukkan proses fase penyembuhan memasuki fase proliferasi (Ariando, 2013). Pada fase proliferasi dibantu oleh fibrolas yaitu sel yang menghasilkan kolagen (Sentat \& Permatasari, 2015). Kolagen akan bekerja menghubungkan jaringan pada luka bakar untuk mengembalikan jaringan kulit dan mempercepat penyembuhan luka bakar. (Ariando, 2013). 
Tahap terakhir adalah fase maturasi (remodeling). Fase maturasi mulai terjadi pada saat terlepasnya scab dan terlihat jaringan kulit yang baru (Sentat \& Permatasari, 2015). Lepasnya scab terjadi karena jaringan dibawahnya sudah kering dan tepi-tepi luka mulai tertarik ke bagian tengah (Aponno dkk, 2014 dalam Sentat \& Permatasari, 2015).

Pengukuran luka bakar dilakukan untuk mengetahui aktivitas penyembuhan luka bakar dan pengaruh konsentrasi ekstrak etanolik daun mengkudu. Kemampuan penyembuhan luka bakar terlihat dari berkurangnya diameter luka dan meningkatnya persentase penyembuhan luka pada setiap perlakuan. Semakin kecil ukuran diameter luka, maka semakin besar persentase penyembuhan luka bakar. Grafik persentase penyembuhan luka bakar dapat dilihat pada Gambar 1.

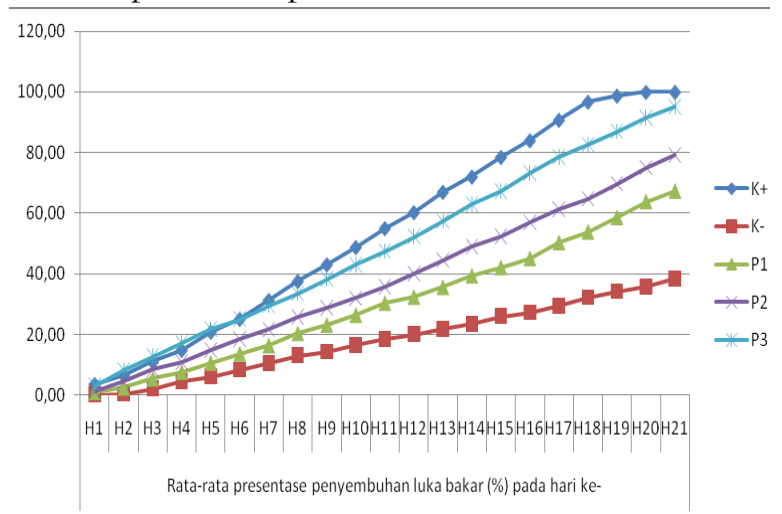

\section{Gambar 1. Grafik Persentase Penyembuhan Luka Bakar}

Keterangan :

$\mathrm{K}+=$ Luka bakar dioles Bioplacenton gel

$\mathrm{K}$ - = Luka bakar dioles vaselin flavum

P1 = Luka bakar dioles ekstrak etanolik daun mengkudu konsentrasi 10\% dalam vaselin flavum

P2 = Luka bakar dioles ekstrak etanolik daun mengkudu konsentrasi 15\% dalam vaselin flavum

P3 = Luka bakar dioles ekstrak etanolik daun mengkudu konsentrasi 20\% dalam vaselin flavum

Persentase penyembuhan luka bakar, kemudian dianalisis secara statistik non parametrik dengan Kruskal-wallis. Hasil analisis statistik menunjukkan bahwa setiap perlakuan menghasilkan perbedaan signifikan terhadap penyembuhan luka bakar, diperoleh nilai $p$ value sebesar $0,000 \quad(\mathrm{P}<0,05)$. Hasil statistik dilanjutkan dengan uji Mann-Whitney. Hasil pengujian Mann Whitney memberikan perbedaan signifikan terhadap perlakuan vaselin flavum dan Bioplacenton gel, namun perbedaan konsentrasi ekstrak etanolik daun mengkudu tidak memberikan perbedaan signifikan terhadap penyembuhan luka bakar.

Perlakuan ekstrak etanolik daun mengkudu menunjukkan adanya perbedaan signifikan terhadap kontrol negatif, karena vaselin flavum merupakan basis salep yang berfungsi hanya sebagai penutup luka tanpa memberikan efek penyembuhan yang berarti sehingga tidak berpengaruh terhadap kecepatan penyembuhan luka bakar. Pada perlakuan ekstrak etanolik daun mengkudu menunjukkan adanya perbedaan signifikan terhadap kontrol positif karena dalam Bioplasenton gel terkandung bahan obat sintetik, yaitu ekstrak placenta dan neomisin sulfat. Ekstrak plasenta bekerja memicu pembentukan jaringan baru, sedangkan neomisin sulfat bekerja mencegah infeksi bakteri pada luka sehingga membantu proses penyembuhan luka (Nur, 2017).

Ekstrak etanolik daun mengkudu pada konsentrasi $10 \%, 15 \%$, dan $20 \%$ secara statistik tidak memberikan perbedaan yang signifikan karena selisih perbedaan konsentrasi yang digunakan memiliki rentang yang tidak jauh berbeda. Proses penyembuhan luka bakar pada ekstrak etanolik daun mengkudu 20\% memberikan efek penyembuhan paling cepat dibandingkan konsentrasi $15 \%$ dan 10\%, dikarenakan semakin tinggi konsentrasi yang digunakan maka semakin besar kandungan senyawa aktifnya sehingga potensi sebagai penyembuh luka bakar juga semakin meningkat (Senja dkk, 2017). Hasil penelitian ini, sejalan dengan penelitian Senja, dkk (2017) pada uji efektivitas ekstrak etanol daun mengkudu terhadap luka sayat pada kelinci jantan, bahwa tidak terdapat perbedaan yang signifikan pada konsentrasi ekstrak daun mengkudu sebesar $10 \%, 15 \%$, dan $20 \%$.

Aktivitas penyembuhan luka bakar pada ekstrak etanolik daun mengkudu dikarenakan adanya kandungan senyawa alkaloid, flavonoid, saponin dan tanin dalam skrining fitokimia. Alkaloid bekerja sebagai antimikroba dengan mekanisme mengganggu komponen penyusun peptidoglikan pada sel bakteri sehingga lapisan dinding sel tidak terbentuk secara utuh dan menyebabkan kematian sel (Paju dkk, 2013). Senyawa flavonoid bekerja sebagai antiinflamasi dengan menghambat permeabilitas kapiler dan 
menghambat metabolisme asam arakidonat dan menghambat sekresi enzim lisosom sebagai mediator inflamasi yang dapat menghambat proliferasi dari proses peradangan (Robinson, 1995). Flavonoid juga berfungsi sebagai antioksidan yang bekerja dengan menginhibisi proses lipid peroksidasi yaitu meningkatkan serabut kolagen, mencegah kerusakan sel, dan membantu sintesis DNA (Nanda, 2018). Senyawa saponin akan menstimulasi pembentukan kolagen yang berperan dalam meningkatkan epitelisasi jaringan, sehingga dapat menutup permukaan luka (Syamsuhidayat dkk, 2004). Senyawa tanin berfungsi sebagai astringensia. Mekanisme kerja tanin sebagai astringensia yaitu dengan mengecilkan pori-pori kulit dan menghentikan eskudat serta pendarahan sehingga mampu menutup luka (Izzati, 2015).

\section{Kesimpulan}

Berdasarkan hasil penelitian dapat disimpulkan bahwa ekstrak etanolik daun mengkudu mengandung senyawa alkaloid, flavonoid, saponin dan tanin yang memiliki aktivitas penyembuhan luka bakar pada kulit kelinci. Adanya perbedaan variasi konsentrasi $10 \% ; 15 \%$ dan $20 \%$ pada ekstrak etanolik daun mengkudu tidak berpengaruh secara signifikan terhadap penyembuhan luka bakar pada kulit kelinci.

\section{Daftar Pustaka}

Ariando, A.B., 2013. Uji Efektivitas Ekstrak Daun Pandan (Pandanus amarillifolius Roxb.) Terhadap Penyembuhan Luka Bakar pada Punggung Kelinci. Karya Tulis Ilmiah. Semarang: Akademi Farmasi Theresiana.

Ardabili, F.M., Abdi, S., Ghezeljeh, T.N., Hosseini, A.F., \& Teymoori. 2016. Evaluation of the Effects of PatientSelected Music Therapy on the Sleep Quality and Pain Intensity of Burn Patients. Medical-Surgical Nursing Journal, 5(2):27-34.

Depkes RI. 2000. Parameter Standar Umum Ekstrak Tumbuban Obat. Jakarta: Depertemen Kesehatan Republik Indonesia.

Erlia, E., Noor, C., \& Dina, R. 2014. Pengaruh Pemberian Gel Kuersetin Terhadap Jumlah Neutrofil dan Limfosit dalam Proses Penyembuhan Luka Bakar Derajat II A Pada Tikus Jantan Galur Wistar. Jurnal
Farmasi. FMIPA Universitas Lambung Mangkurat.

Gurnida, D.A., \& Lilisari, M. 2011. Dukungan Nutrisi pada Penderita Luka Bakar. Bandung: Bagian Ilmu Kesehatan. Fakultas Kedokteran Universitas Padjajaran.

Izzati, U.F. 2015. Efektivitas Penyembuhan Luka Bakar Salep Ekstrak Etanol Daun Senggani (Melastoma malabatharicum L.) Pada Tikus (Rattus norvegicus) Jantan Galur Wistar. Skripsi Farmasi. Pontianak: Universitas Tanjungpura.

Jones, W.P., \& Kinghorn, A.D. 2006. Extraction of Plant Secondary Metabolites, In: Sharker, S. D. Latif Z, Gray A.L, eds. Natural Product Isolation $2^{\text {nd }}$ Edition. New Jarsey. Humana Press.

Nanda, T.I. 2018. Uji Efektivitas Fraksi nHeksana Daun Mengkudu (Morinda citrifolia L.) dengan Pembawa Vaselin terhadap penyembuhan Luka Sayat pada Tikus. Skripsi Farmasi. Universitas Sumatera Utara.

Nugrahani, R., Andayani, Y., \& Hakim, A. 2016. Skrining Fitokimia dari Ekstrak Buah Buncis (Phaseolus vulgaris L.) dalam Sediaan Serbuk. Jurnal Pendidikan IPA. Vo. 2 No. 1. E-ISSN:2407-795x.

Nur, N.N. 2017. Perbedaan Penyembuhan Luka Sayat Secara Makroskopis Antara Pemberian Topikal Ekstrak Sel Punca Mesenkimal Tali Pusat Manusia Dengan Gel Bioplacenton Pada Tikus Putih Jantan Galur Sprague Dawley. Skripsi. Fakultas Kedokteran Universitas Lampung.

Moenadjat, Y. 2009. Luka Bakar dan Tatalaksana Edisi ke-4. Jakarta: Fakultas Kedokteran UI.

Paju, N., Yamlean, P.V.Y., \& Kojong, N. 2013. Uji Efektivitas Salep Ekstrak Daun Binahong (Anredera cordifolia (ten.) Steenis) pada Kelinci (Oryctolagus cuniculus) yang Terinfeksi Bakteri Staphylococcus aureus. Pharmacon Jurnal Imliah Farmasi. 2(1).

Razak, A., \& Ervianingsih. 2017. Uji Efektivitas Ekstrak Buah Tomat (Solanum lycopersicum) Terhadap Penyembuhan Luka Bakar Pada Hewan Uji Kelinci, Borneo Journal Pharmascientech, Vol 01, No. 02, ISSN- Print. 2541 - 3651.

Robinson, T. 1995. Kandugan Organik Tumbuban Tingkat Tinggi. Bandung: ITB. 
Senja, R.Y., Hidayati, N. R., \& Setyaningsih. I. 2017. Uji Efektivitas Salep Ekstrak Daun Mengkudu (Morinda citrifolia L.) Terhadap Luka Sayat Pada Kelinci Jantan. Jurnal Medical Sains.

Sentat, T., \& Permatasari, R. 2015. Uji Aktivitas Ekstrak Etanol Daun Alpukat (Persea americana Mill.) Terhadap Penyembuhan Luka Bakar Pada Punggung Mencit Putih Jantan (Mus musculus) Jurnal Ilmiah Manuntung, ISSN 2477-1821.

Suyatno \& Rizky, T.A. 2014. Aktivitas Antioksidan Dan Antikanker Ekstrak Metanol Tumbuhan Paku Adiantum philippensis L. UNESA Journal of Chemistry Vol. 3 No. 1.
Syamsuhidayat, R \& Jong, W.D. 2004. Buku Ajar Ilmu Bedah: Luka Bakar. Erlangga: Jakarta.

West, B.J., Deng, S., Palu, A.K., \& Jensen, C.J., 2009. Morinda citrifolia Linn. Leaf Extracts Mitigate UVB-Induced Erythema. Journal National Medication.

Wijaya, A.S \& Putri, Y.M. 2013. Keperawatan Medikal Bedah 2, Keperawatan Dewasa Teori dan Contoh Askep. Yogyakarta: Nuha Medika. 